
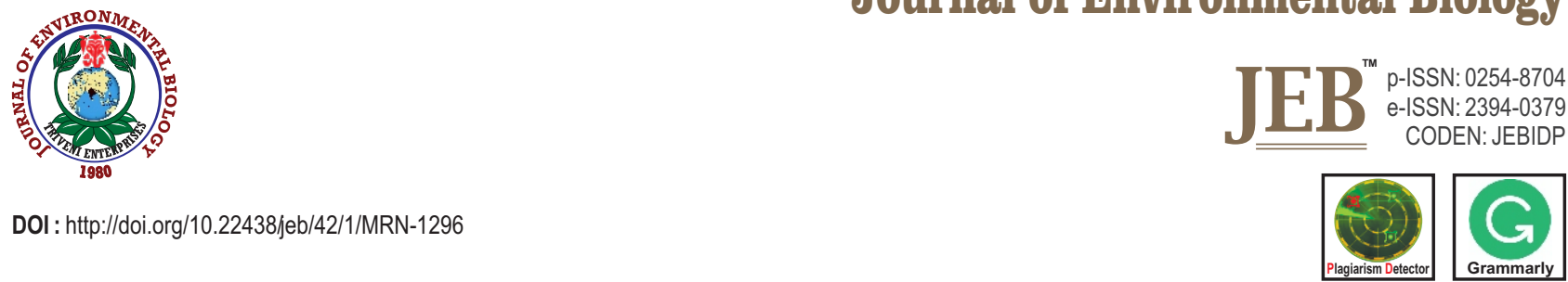

\title{
Incidence and severity of cotton leaf curl virus disease on different BG II hybrids and its effect on the yield and quality of cotton crop
}

\author{
D. Monga and S.K. Sain* \\ ICAR-Central Institute for Cotton Research, Regional Station, Sirsa-125055, India \\ *Corresponding Author Email : sain.skumar@gmail.com
}

\section{Abstract}

Aim: To understand the effect of Cotton Leaf Curl Disease incidence and severity at various crop growth stages on Bollgaurd-Il cotton hybrids having different levels of susceptibility and resistance and its effect on, seed cotton yield and fibre quality.

Methodology: The effect of cotton leaf curl disease (CLCUD) incidence, severity and its progress on highly resistant to susceptible cultivars was compared. The loss of seed cotton yield (SCY) corresponding to CLCuD incidence at 80 DAS, 81-110 DAS, 111-140 DAS was estimated separately in each hybrid. The loss of fibre quality corresponding to $\mathrm{CLCUD}$ incidence at seven different stages, i.e., 50 to 140 days after sowing (DAS) was also calculated.

Results: The highest relative area under disease progress curve (AUDPC) values of PDI were observed in Ankur 3028 (100\%) and Ankur Jai BG II (83\%), while the lowest values were recorded in highly resistant hybrids Yuva-841-2 (4.6\%) and Bunty 2113-2 $(13.8 \%)$. When the disease appeared up to 80 DAS compared to 110,140 DAS the reduction range in SCY (4.6-62.4\%), fibre length (23.9-29.9\%), strength (21.4-30.1\%) and uniformity (62.5-83\%) was recorded to be higher in susceptible hybrids. The fibre length, strength, and uniformity were reduced in diseased plant $(25.9 \mathrm{~mm}$, $24.4 \mathrm{~g} / \mathrm{tex}, 68.2 \%$ ) when incidence took place at 50 DAS compared to disease-free plants $(27.6 \mathrm{~mm}, 25.9 \mathrm{~g} / \mathrm{tex}, 72.9 \%)$. However, reduction in SCY, fiber length, fiber strength and uniformity at $80 \mathrm{DAS}$ varied with respect to hybrid and their resistance category.

Interpretation: These results provide the basis to prove the hypothesis that the yield loss is associated with the stage of CLCUD incidence and its severity in cotton hybrids with different levels of resistance as well as its genetic potential of a particular cotton cultivar. However, the extent of yield reduction within the resistant or susceptible category is also dependent on the yield potential of a particular cultivar. Thus, breeders must consider both the criteria-lower PDI /AUDPC and higher productivity to select high yielding cotton lines.

Key words: Cotton, Disease index, Leaf Curl Disease, Virus

How to cite : Monga, D. and S.K. Sain: Incidence and severity of cotton leaf curl virus disease on different BG II hybrids and its effect on the yield and quality of cotton crop. J. Environ. Biol., 42, 90-98 (2021). 


\section{Introduction}

Worldwide, cotton (Gossypium spp.) is the most important fibre, oil, and protein yielding crop. Currently, India is the world's top producer of cotton. It is grown in tropical and subtropical regions of more than 80 countries and contributes about $65 \%$ of the raw material for textile industry. In India, it is cultivated in eleven states, both under irrigated $(40 \%)$ and rain-fed (60\%) conditions, and is the most important Kharif cash crop of North India. Main reasons for low productivity of cotton in North India are attributed to high incidence of cotton leaf curl disease (CLCuD), which is considered as the most complex and economically important disease of cotton (Monga, 2016; Sattar et al., 2017; Naveen et al., 2017). The CLCuD system was amongst the first in which single-stranded DNA satellites associated with geminiviruses were identified (Briddon and Stanley, 2006).

The viral agents associated with this disease are collectively known as CLCuD associated begomoviruses (CABs), which belong to the genus Begomovirus (family Geminiviridae), and are transmitted by whitefly (Bemisia tabaci) (Brown et al., 2015; Monga, 2016; Zerbini et al., 2017). CLCuD can be identified by small vein thickening (SVT) type symptoms initially on young upper leaves. These irregular thickenings gradually extend and coalesce to form continuous reticulation of small veins. The disease is further characterized by upward or downward curling of leaves and affected leaves become thick, leathery, brittle and greener than healthy leaves. Later, the formation of a cup-shaped or leaf laminar outgrowth called "enation" appears on the underside of the leaf. In Asia, cotton has faced two major epidemics during this period viz. "Multan epidemic" and "Burewala epidemic." Multan epidemic occurred during 1988-1999, after which the virus remained calm until 2002 but during 2003 "Burewala epidemic" caused by Cotton Leaf Curl Burewala Virus (CLCuBuV) broke into the cotton fields in Indo-Pak subcontinent, and continued till 2013-2014 (Sattar et al., 2017). Most recently the rebound of Cotton Leaf Curl Multan Virus (CLCuMuV) in northern Indian zone was suggested (Datta et al., 2017). CLCuD appeared in Pakistan in epidemic form during 1992-93 which decreased the production to 9.05 million bales and during 1993-94 season to 8.04 million bales (Mahmood et al., 2003). The financial losses with the estimated value of $\$ 5$ billion (US) to the nation occurred from 1992-97 (Briddon and Markham, 2001).

According to the findings of Ahmad et al. (2002) in Pakistan, CLCuD caused reduction in plant height (40.5\%), boll weight $(42.5 \%)$ and number of bolls per plant $(86 \%)$, fibre length $(7.1 \%)$ in susceptible cotton cultivars. Due to CLCuD incidence fiber quality traits like ginning out turn, fiber length, fiber uniformity index, fiber fineness, fiber bundle strength, maturity ratio deteriorated because of change in the composition of major fiber components, including cellulose, protein, wax and pectin (Farooq et al., 2015). Considerable seed cotton yield (SCY) reduction in Rajasthan (32.9 to $50.3 \%$ ), Punjab (10.5 to $92.2 \%$ ) and Haryana (39.4 to $81.4 \%$ ) states of North India has been reported (Monga et al., 2001). Reduction due to CLCuD incidence in the SCY (10.5-
92.2\%), boll number (12.3 - 64.7\%) and boll weight (42.9 - 72.3\%) has been reported in cotton (Singh, 2006; Monga, 2014). Saeed et al. $(2014 \mathrm{a}, \mathrm{b})$ showed a negative significant correlation of CLCUD with monopodial branches, sympodial branches and plant height. In yet another study, percent maximum loss in SCY was observed in hybrid Jai BG (54.1) followed by MRC 7361 BG (48.8) and Solar 76 BG (46.8) (Monga et al., 2011). CLCuD exhibited a negative and significant association with SCY, ginning outturn \%, number of bolls (Saeed et al., 2014a; Farooq et al., 2013). However, on the other hand, boll weight and SCY had significant positive genotypic and phenotypic correlations with SCY, ginning outturn, 100-seed weight, number of bolls per plant, petiole length, leaf width, leaf length, number of sympodial branches per plant, number of nodes to $1^{\text {st }}$ monopodium, and plant height (Javed et al., 2016). Significant associations were found between yield contributing trait, boll weight and fiber related trait, staple length. Earliness related traits, like days taken to 1 square stand days taken to 1 flower had a positive correlation with each other and both these traits also showed their association with ginning outturn (Ali et al., 2009; Farooq et al., 2013).

Maximum CLCuV incidence was recorded within 30-45 days in late planting as compared to 105 days of early planted cotton (Hussain et al., 2015). The occurrence of disease at an early and or late-stage may have a different effect on the SCY. However, the losses estimated in previous studies in the response of CLCuD grading did not clarify the effect of incidence of $\mathrm{CLCuD}$ on yield and it's quality components of cotton cultivars having varied resistance levels at various crop growth stages. There is no research work available to date, which indicates the effect of incidence and progress of CLCUD with the yield. Considering these facts in mind, the present investigation was undertaken to understand the relationship between CLCuD incidence, progress and CLCuD severity in both highly resistant/tolerant and susceptible Bt cotton hybrids. corresponding to yield and quality reduction.

\section{Materials and Methods}

Field experimental layout: Two field experiments were conducted at the research farm of the Indian Council of Agricultural Research - Central Institute for Cotton Research (ICAR-CICR), Regional Station Sirsa for three consecutive years from 2014 to 2016. Progress in incidence and severity of cotton leaf curl virus disease (CLCuD) and its effect on seed cotton yield (SCY) and quality of cotton hybrids (Bollgard II) with different levels of resistance was studied. Cotton hybrids (Bollgard II) namely RCH 650 BGII (moderately resistance/MR); RCH 653 (moderately susceptible/MS); NCS 855 (MS); Bioseed 6488 (MS); Yuva-841-2 (highly resistant/HR); Bunty 2113-2 (HR), Ankur Ji (susceptible/S); Ankur 3028 (S) were used to evaluate the effect of disease progress on yield and quality.

During 2014 and 2015, five commercially popular Bollgard II cotton hybrids RCH 650 (MR), RCH 653 (MS), Bioseed 6488 (MS) NCS 855 (MS), and Ankur 3028 (S) were sown on $5^{\text {th }}$ 
May 2014 and $2^{\text {nd }}$ May 2015 with a spacing of $67.5 \times 60 \mathrm{~cm}$. One row, each of CLCuD susceptible variety HS 6 was sown as infector row on both sides of hybrid for CLCuD inoculum multiplication and spread of disease through whitefly. In the second experiment, two CLCuD tolerant/highly resistant hybrids (Yuva-841-2 and Bunty 2113-2) and two susceptible (Ankur Jai and Ankur 3028) hybrids were sown on $2^{\text {nd }}$ May 2015 and 20 April 2016. The recommended package of practices was followed for raising the crop.

Recording of observations: Data on CLCUD incidence was collected at 15 days interval, starting from 50 days after planting and continued up to140 days. A total of seven observations were recorded. The total number of plants showing leaf curl virus disease symptoms (upward curling with thickened veins on the underside of the leaf) were counted every time during the observations and percent disease incidence was calculated as given below: Percent disease incidence $=($ Infected plants $/$ Total plants) $\times 100$. At the time of each observation, plants with CLCuD incidence were tagged indicating the date of observation. Subsequently, at each next observation, new plants with CLCuD incidence were tagged. Later at 80, 110 and 140 DAS, each plant with CLCuD symptom was graded (at 80 days, the total plants as on that date, including the previous ones were also graded) according to standard 0-6 rating scale for CLCuD (Monga, 2014).

In the case of 110 DAS, the total plants showed CLCuD incidence after 80 and up to 110 days were graded and similarly, for 140 DAS, the total plants showed CLCuD incidence from 110 up to 140 days were graded. Percent disease index/severity (PDI) was calculated by following the formula: $P D I=($ Sum of all grades /Total number of plants $\div$ maximum severity grade) $\times 100$. Using the following formula of Wilcoxson et al. (1975) as a measure of CLCuD resistance, the area under disease progress curve (AUDPC) was calculated for individual plants/hybrids from the calculated disease rating values of the original CLCUD severity data collected at 50,65, 80,95, 110, 125 and 140 DAS as well as PDI data at 80,110 and 140 DAS. AUDPC $=\Sigma[(X i+X i+1) / 2]$ ti - t. Where, $\mathrm{Xi}$ and $\mathrm{Xi}+1$ are severity in the form of percent CLCuD incidence on the date $\mathrm{i}$ and date $\mathrm{I}+1$, respectively, and $t i$ is the number of days between date I and date I +1 . Further, to compare the disease severity and incidence percent in each cultivar the relative AUDPC ( $r A U D P C)$ was calculated by dividing the AUDPC in cultivars by the "maximum potential AUDPC" or using the formula as follows: rAUDPC= (AUDPC of the cultivar/AUDPC of the most susceptible cultivars/ maximumAUDPC) $\times 100$.

Fully opened bolls from each plant that were tagged for the presence of CLCuD at various DAS were picked separately for each category of CLCUD incidence dates for taking yield. The yield was recorded for diseased plants separately in three groups, i.e., total plants which showed PDI up to 80 days followed by total plants which showed disease after 80 and up to 110 days and in plants where disease appeared between 110 to 140 days. Plants free off CLCuD incidence were also counted and their yield data were recorded separately for each hybrid. The percent reduction in SCY when the disease appeared up to 80 , between 80 and 110 and between 110 and 140 DAS was calculated by comparing it with the yield of healthy plants.

The data on fibre quality such as $2.5 \%$ span length $(\mathrm{mm})$, uniformity $(\%)$, fibre strength $\left(\mathrm{g} \mathrm{tex}^{-1}\right)$, and micronaire value $\left(\mathrm{g} \mathrm{inch}^{-1}\right)$ at crop maturity were recorded from opened bolls of each plant that were tagged for the presence of CLCUD at various days after sowing (DAS). Each category treatment was replicated thrice. The statistical analyses were performed using the OP Stats (Sheoran et al., 1998). The standard error of means (SEM) was calculated for each treatment and used for comparison. Comparison across 3 years was made using analysis of variance (ANOVA) followed by Fisher's Least Significant Difference (LSD) test for comparison. Data for all the experimental parameters were pooled for both the year for comparison and drawing the results and conclusion.

\section{Results and Discussion}

An increase in CLCuD incidence from 50 to 140 days after sowing (DAS) was noted in different Bt hybrids in the present study. The pooled CLCuD incidence (\%) under different disease reaction categories during 2014 and 2015 at 50 DAS ranged between 2.4-4.6 whereas at 140 DAS it was 55.1-86.1. However, during 2015 and 2016 the incidence (\%) under different disease reaction categories varied between $0.0-1.9$ at 50 DAS and 9.478.5 at 140 DAS (Table 1). The AUDPC values for CLCuD incidence differed considerably for different cotton genotypes during all the experimental years. The highest relative AUDPC value for CLCuD incidence was observed in susceptible hybrid Ankur 3028 (100\%), Ankur Jai (94.7\%), while the lowest AUPDC value was recorded in highly resistant hybrid Yuva-841-2 (7.9\%) followed by Bunty 2113-2 (22.6\%) (Table 1).

The pooled percent disease index (PDI) under different disease reaction categories during 2014 and 2015 at 50 DAS ranged between $3.7-11.3 \%$ whereas at 140 DAS it was 21.249.1\%. However, during 2015 and 2016 the PDI varied between $0.4-14.8 \%$ at 50 DAS and $3.6-43.2 \%$ at 140 DAS. The highest relative AUDPC value for CLCUD PDI was recorded in susceptible hybrid Ankur 3028 (100\%) and Ankur Jai (83\%), while the lowest relative AUPDC value was observed in highly resistant hybrid Yuva-841-2 (4.6\%) followed by Bunty 2113-2 (13.8\%) (Table 2). Monga et al. (2016) showed that PDI increases slowly during the month of June and reaches up to $80 \%$ during August and September. Despite almost 10 years of efforts in Pakistan since the appearance of the 'Burewala' strain of $\mathrm{CLCuD}$, conventional breeding has not been entirely successful in yielding resistance to disease (Farooq et al., 2011).

Some promising lines with good tolerance, but that still support virus infection, exhibit mild symptoms and nevertheless provide acceptable yields, have been identified (Rahman and Zafar, 2007). In the present study, hybrid Bunty 2113-2 showed slower disease progress and at the same time also showed 
Table 1: Percent incidence of CLCuD in different Bt hybrids infected with CLCuD at different days after sowing (DAS) during three consecutive years from 2014 to 2016. The data is an average of three replications and two years (2014-2015 and 2015-2016) studies

\begin{tabular}{|c|c|c|c|c|c|c|c|c|c|c|}
\hline \multirow[t]{2}{*}{ Hybrid } & \multirow[t]{2}{*}{ Year } & \multicolumn{7}{|c|}{ CLCuD incidence $(\%)$ at different days after sowing (DAS)* } & \multirow[t]{2}{*}{ AUDPC } & \multirow[t]{2}{*}{ rAUDPC } \\
\hline & & 50 & 65 & 80 & 95 & 110 & 125 & 140 & & \\
\hline RCH 650 (MR) & 2014-15 & 3.8 & 5.2 & 13.5 & 21.5 & 28.3 & 46.6 & 55.1 & 2262.8 & 46.8 \\
\hline RCH 653 (MR) & 2014-15 & 2.3 & 5.9 & 13.5 & 17.2 & 27.7 & 59.8 & 70.7 & 2466.9 & 51.0 \\
\hline Bioseed 6488 (MR) & 2014-15 & 4.6 & 8.2 & 13.2 & 22.4 & 29.2 & 56.4 & 66.2 & 2587.4 & 53.5 \\
\hline NCS 855 (MS) & 2014-15 & 2.2 & 8.5 & 15.9 & 23.8 & 35.5 & 72.6 & 86.1 & 3060.7 & 63.3 \\
\hline Ankur 3028 (S) & 2014-15 & 2.4 & 4.6 & 17.7 & 28.3 & 41.3 & 62.1 & 67.4 & 2891.1 & 59.8 \\
\hline Yuva-841-2 (HR) & $2015-16$ & 0.0 & 0.1 & 2.5 & 3.9 & 5.5 & 8.8 & 9.4 & 380.9 & 7.9 \\
\hline Bunty 2113-2 (HR) & $2015-16$ & 0.0 & 0.9 & 7.2 & 13.8 & 16.1 & 21.5 & 26.9 & 1093.4 & 22.6 \\
\hline Ankur Jai (S) & $2015-16$ & 1.0 & 15.3 & 54.6 & 60.8 & 63.9 & 71.0 & 74.3 & 4576.8 & 94.7 \\
\hline Ankur 3028 (S) & $2015-16$ & 1.9 & 13.2 & 53.9 & 62.3 & 71.1 & 78.1 & 78.5 & 4835.0 & 100.0 \\
\hline \multicolumn{2}{|l|}{ LSD $(p<0.05)$ Variety } & 0.8 & 1.5 & 2.2 & 3.5 & 12.5 & 18.2 & 18.8 & - & - \\
\hline \multicolumn{2}{|c|}{ LSD $(p<0.05)$ Years } & 0.5 & 1.2 & 1.8 & 2.4 & 8.9 & 14.3 & 13.4 & - & - \\
\hline \multicolumn{2}{|c|}{ LSD $(p<0.05)$ Variety $x$ Year } & 0.4 & 0.9 & 1.1 & 1.9 & 7.4 & 11.5 & 10.5 & - & - \\
\hline
\end{tabular}

Table 2: Percent disease index (PDI) of CLCuD in different Bt hybrids infected with CLCuD at different days after sowing (DAS) during three consecutive years from 2014 to 2016. The data is an average of three replications and two years (2014-2015 and 2015-2016) studies

\begin{tabular}{|c|c|c|c|c|c|c|}
\hline \multirow[t]{2}{*}{ Hybrid } & \multirow[t]{2}{*}{ Year } & \multicolumn{3}{|c|}{ PDI of CLCuD at different days after sowing (DAS) } & \multirow[t]{2}{*}{ AUDPC } & \multirow[t]{2}{*}{ rAUDPC } \\
\hline & & Up to 80 DAS & $80-110$ DAS & 111 to 140 DAS & & \\
\hline RCH 650 (MR) & $2014-15$ & 3.7 & 13.2 & 21.2 & 1003.8 & 38.3 \\
\hline $\mathrm{RCH} 653$ (MR) & 2014-15 & 3.9 & 10.9 & 24.9 & 928.7 & 35.4 \\
\hline Bioseed 6488 (MR) & $2014-15$ & 6.6 & 11.9 & 23.1 & 1273.0 & 48.5 \\
\hline NCS 855 (MS) & $2014-15$ & 4.8 & 15.3 & 33.5 & 1231.0 & 46.9 \\
\hline Ankur 3028 (S) & $2014-15$ & 11.3 & 16.6 & 49.1 & 1993.1 & 76.0 \\
\hline Yuva-841-2 (HR) & $2015-16$ & 0.4 & 1.7 & 3.6 & 120.1 & 4.6 \\
\hline Bunty 2113-2 (HR) & $2015-16$ & 1.4 & 4.4 & 8.7 & 361.9 & 13.8 \\
\hline Ankur Jai (S) & $2015-16$ & 11.5 & 19.9 & 43.2 & 2176.8 & 83.0 \\
\hline Ankur 3028 (S) & $2015-16$ & 14.8 & 21.7 & 40.9 & 2622.7 & 100 \\
\hline LSD $(p<0.05)$ Variety & & 4.5 & 1.4 & 3.8 & - & - \\
\hline LSD $(p<0.05)$ Years & & 3.8 & 0.9 & 2.5 & - & - \\
\hline LSD $(p<0.05)$ Variety $x$ Year & & 2.3 & 0.7 & 1.8 & - & - \\
\hline
\end{tabular}

higher yields. This approach can be successful as consistent resistant sources are not available due to frequent development of viral recombinants. The present study was conducted to understand the relationship between CLCuD incidencel occurrence, progress, relative AUDPC and CLCuD severity corresponding to the yield reduction in both tolerant and susceptible hybrids indicating that the lower incidence of CLCUD occurred in highly resistant cultivar at 65 DAS compared to moderately resistance, moderately susceptible and susceptible in which the CLCuD incidence occurred even 50 days after sowing. The CLCuD incidence occurred 80 DAS in highly resistant cotton cultivars. The lower PDI at $140 \mathrm{DAS}$ was recorded in highly resistant cotton cultivars as compared to moderately resistant, moderately susceptible and susceptible cultivars (Table 1, 2; Fig.1).

The AUDPC and relative AUDPC values for CLCuD incidence and CLCUD PDI also differed in similar trends for different cotton genotypes during all the experimental years. Based on two-year pooled average, the highest relative AUDPC value for CLCuD PDI was recorded in susceptible hybrids, followed by moderately susceptible, moderately resistant and highly resistant hybrids (Table 1, 2). It is hypothesized that there is a similar trend between percent incidence and PDI. As the initial low incidence and its slow progress are responsible for final low incidence and percent disease severity, this information can be used to select the tolerant hybrids. The delayed initiation of disease in case of tolerant hybrids by two weeks and their subsequent slow progress/relative AUDPC can be a useful indicator to select Bt cotton hybrids tolerant against CLCUD. The lower relative AUDPC value indicates the resistance/tolerance level of a particular hybrid against CLCuD incidence, its progress and severity. Hussain et al. (2015) also reported that the maximum CLCuV incidence occurred within 30-45 days in late planting as compared to 105 days of early planted cotton. 
Table 3: Average seed cotton yield per plant and percent reduction in different Bt hybrids infected with CLCuD at different days after sowing (DAS) during three consecutive years from 2014 to 2016. The data is an average of three replications and two years (2014-2015 and 2015-2016) studies

\begin{tabular}{|c|c|c|c|c|c|c|c|c|}
\hline \multirow{3}{*}{ Treatment } & \multirow{3}{*}{ Year } & \multicolumn{6}{|c|}{ Seed cotton yield (g/plant) } & \\
\hline & & \multirow{2}{*}{$\begin{array}{l}\text { CLCuD } \\
\text { free plant }\end{array}$} & \multicolumn{2}{|c|}{ Up to 80 DAS } & \multicolumn{2}{|c|}{ 80-110 DAS } & \multicolumn{2}{|c|}{111 to $140 \mathrm{DAS}$} \\
\hline & & & Yield & $\%$ reduction & Yield & $\%$ reduction & Yield & $\%$ reduction \\
\hline RCH 650 (MR) & 2014-15 & 101.0 & 52.6 & 45.6 & 65.8 & 34.7 & 69.4 & 31.1 \\
\hline $\mathrm{RCH} 653$ (MR) & $2014-15$ & 103.5 & 56.2 & 43.1 & 72.0 & 29.8 & 75.9 & 25.8 \\
\hline Bioseed 6488 (MR) & 2014-15 & 83.5 & 50.5 & 32.7 & 63.6 & 20.2 & 58.1 & 23.4 \\
\hline NCS 855 (MS) & 2014-15 & 82.1 & 47.5 & 39.4 & 58.4 & 26.9 & 58.0 & 26.3 \\
\hline Ankur 3028 (S) & 2014-15 & 137.6 & 57.3 & 41.0 & 65.4 & 33.0 & 62.5 & 38.7 \\
\hline Yuva-841-2 (HR) & $2015-16$ & 70.0 & 74.5 & 4.61 & 71.0 & 9.7 & 70.4 & 8.2 \\
\hline Bunty 2113-2 (HR) & $2015-16$ & 146.1 & 121.1 & 20.3 & 125.3 & 29.0 & 132.7 & 17.2 \\
\hline Ankur Jai (S) & $2015-16$ & 47.9 & 35.0 & 27.7 & 41.0 & 15.2 & 47.9 & 0.0 \\
\hline Ankur 3028 (S) & $2015-16$ & 172.8 & 60.4 & 62.4 & 67.0 & 58.5 & 86.7 & 45.3 \\
\hline \multicolumn{2}{|l|}{$\mathrm{LSD}(\mathrm{p}<0.05)$ Variety } & 20.2 & 12.4 & - & 14.5 & - & 18.2 & - \\
\hline \multicolumn{2}{|l|}{ LSD $(p<0.05)$ Years } & 15.3 & 15.8 & - & 11.6 & - & 12.3 & - \\
\hline \multicolumn{2}{|c|}{ LSD $(p<0.05)$ Variety $\times$ Year } & 8.4 & 7.2 & - & 8.3 & - & 8.6 & - \\
\hline
\end{tabular}

Table 4: Pooled fibre quality, micronaire value, and fibre strength, span length, and uniformity in different Bt hybrids infected with CLCuD at different days after sowing during three consecutive years from 2014 to 2016. The data is the overall average of all the Bt hybrids with three replications during two years (2014-2015 and 2015-2016) studies

\begin{tabular}{lllllllll}
\hline Quality parameter & \multicolumn{7}{c}{ CLCuD incidence (\%) at different days after sowing (DAS) } \\
\cline { 2 - 8 } & $\mathbf{5 0}$ & $\mathbf{6 5}$ & $\mathbf{8 0}$ & $\mathbf{9 5}$ & $\mathbf{1 1 0}$ & $\mathbf{1 2 5}$ & 140 & Free plants \\
\hline Micronaire value (\%) & 4.4 & 4.3 & 4.3 & 4.3 & 4.4 & 4.3 & 4.4 & 4.3 \\
Range & $3.8-4.9$ & $3.8-4.6$ & $4.1-4.7$ & $3.9-4.7$ & $4.0-4.8$ & $4.0-4.8$ & $4.0-4.8$ & $3.9-4.8$ \\
Fibre strength (g per tex) & 24.4 & 24.5 & 25.0 & 25.4 & 24.9 & 25.2 & 25.3 & 25.9 \\
Range & $21.4-28.6$ & $21.9-28.7$ & $21.6-29.7$ & $22.0-29.5$ & $22.1-29.4$ & $21.6-29.5$ & $21.7-29.5$ & $23.0-30.1$ \\
2.5\% span length (mm) & 25.9 & 26.5 & 27.0 & 26.9 & 26.8 & 27.0 & 26.9 & 27.6 \\
Range & $23.1-28.1$ & $24.2-28.7$ & $24.9-28.7$ & $25.1-29.3$ & $24.7-28.9$ & $24.7-29.0$ & $24.2-29.1$ & $26.2-29.2$ \\
Uniformity (\%) & 68.2 & 70.0 & 72.0 & 72.2 & 72.1 & 72.0 & 72.5 & 72.9 \\
Range & $62.5-82.0$ & $63.5-82.5$ & $64.0-82.5$ & $63.5-82.5$ & $63.5-82.5$ & $64.0-82.5$ & $64.0-82.5$ & $64.0-83.0$ \\
\hline
\end{tabular}

The effect on SCY was estimated from each hybrid where CLCuD incidence under all CLCuD grading occurred up to 80 , between 80 and 110 and between 110 and 140 days after sowing. The yield of disease-free plants in each hybrid was also recorded for comparing the reduction. Overall, the average SCY reduction was higher during the year 2016 and 2014 compared to 2015, irrespective of all cultivars. The percent SCY reduction, in general, was more when the disease appeared early as compared to that appeared late in the season. When disease appeared at 80 DAS, the pooled SCY reduction in Bt hybrids during 2014 and 2015 ranged between $39.4-45.6 \%$ whereas, it ranged between 4.6-62.4 percent during 2015 and 2016 . In case of late appearance of disease between 111-140 days after sowing, the yield reduction during 2014 and 2015 varied from 23.4-31.1 and in the case of 2015 and 2016 it ranged between 0.0-45.3. When pooled means were compared, the reduction in seed cotton ranged from 27.7 to $62.4 \%$ in susceptible cultivars, 32.7 to $45.6 \%$ in moderately resistant cultivars, 4.6 to $20.3 \%$ in highly resistant cultivars infected with CLCUD up to 80 days after sowing. The reduction in seed cotton ranged from 15.2 to $58.5 \%$ in susceptible cultivars, 20.2 to $34.7 \%$ in moderately resistant cultivars, 9.7 to $29.0 \%$ in highly resistant cultivars from 80 to 110 DAS CLCuD incidence (Table 3).

We found that in general, the reduction in SCY was lower in highly resistant hybrids and higher in susceptible hybrids due to CLCuD. However, no similar trend was recorded among highly resistant and susceptible cultivars with respect to reduction in SCY and PDI. Further, it was observed that the reduction percent of SCY was higher in the hybrids with high yield potential within their resistance category (Table 3). It was interesting to note that resistant cultures do not necessarily provide good yields. For instance, the disease-free plants of resistant cultivar Yuva-8412 yielded less ( $70 \mathrm{~g}$ per plant) as compared to another resistant cultivar Bunty 2113-2 (146.1 g per plant) exhibiting different genetic yield potentials. Similarly, within the susceptible cultivars, the yield potential was different and the highest yield in disease-free plant was recorded in Ankur 3028 (172.8 g per 


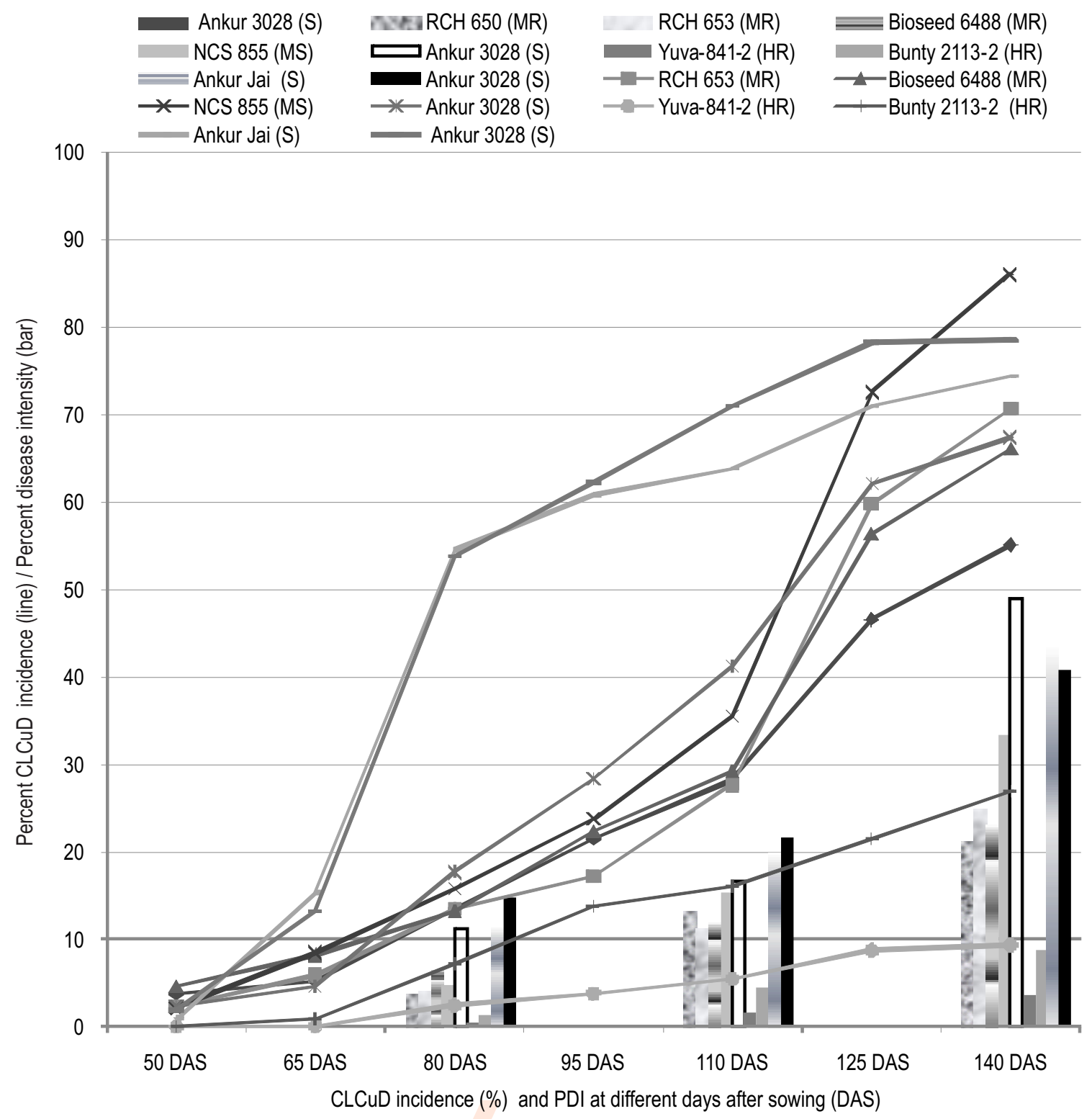

Fig.1: Pooled progress in CLCUD incidence and percent disease index in different Bt hybrids infected with CLCuD at different days after sowing (DAS) (2014 and 15 and 2015 and 2016). HR= Highly resistant; MR=Moderatly resistant; MS=Moderatly susceptible; S= Susceptible; DAS=days after sowing; The line (incidence) and bar (PDI) represent the pooled data of three replications for each variety evaluated during two years (2014- 2015 and 20152016). Mean values within the same line and bar are significantly different at $\operatorname{LSD}(p<0.05) 10.5$ and 2.2 , respectively.

plant) as compared to Ankur Jai (47.9 g per plant). Hence, it was inferred that each hybrid resistant or susceptible has its own yield potential irrespective of its reaction against CLCUD. The yield reduction though was dependent on the time of incidence and severity of CLCuD yet, the extent of yield reduction within the resistant or susceptible category was also dependent on the yield potential of a particular cultivar. Javed et al. (2016) reported that boll weight and SCY had significant positive genotypic and phenotypic correlations with SCY, ginning outturn, 100-seed weight, number of bolls per plant, petiole length, leaf width, leaf length, number of sympodial branches per plant, number of nodes to $1^{\text {st }}$ monopodium and plant height. Significant associations have also been reported between yield contributing trait, boll weight and fiber related trait and staple length (Ali et al., 2009). Earliness related traits, like days taken to 1 square stand days taken to 1 flower had a positive correlation with each other and both these traits also showed their association with ginning outturn (Farooq et al., 2013). Ali et al. (2009) reported significantly 

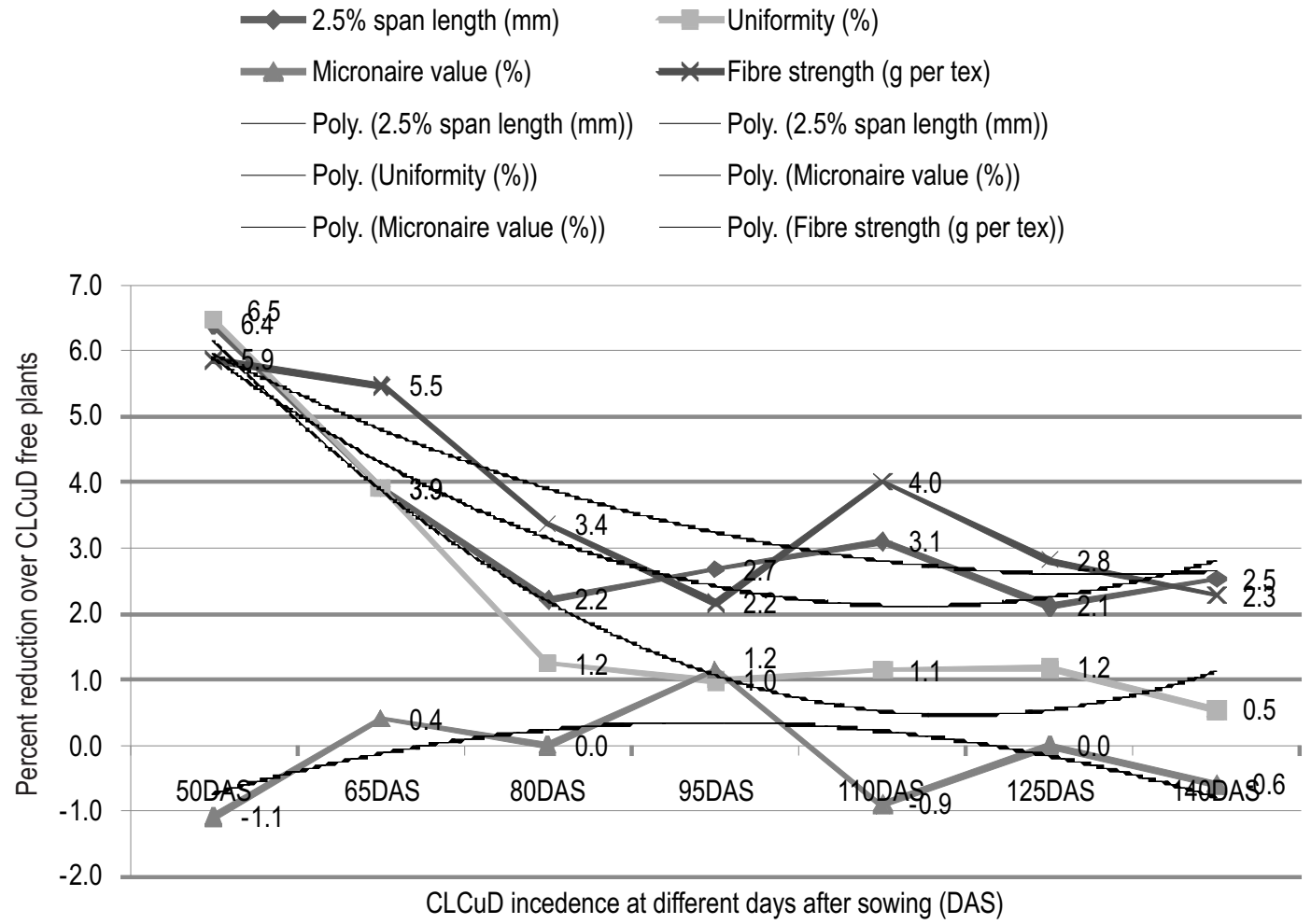

Fig. 2: Pooled effect of CLCUD incidence on the reduction of fibre quality in different Bt hybrids infected with CLCuD at different days after sowing (DAS) (2014 and 15 and 2015 and 2016). The line data is pooled average reduction in different quality characteristics over the healthy plants evaluated during 2014-2015 and 2015-2016; DAS=days after sowing.

negative correlation of CLCuD with monopodial branches, sympodial branches and plant height, while SCY showed positive genotypic association with bolls per plant, plant height and sympodia per plant. A positive correlation of yield with yield contributing traits and negative association between SCY and CLCuD has been reported (Farooq et al. 2013; Saeed et al., 2014b).

The CLCuD was caused huge loss of about $10-90 \%$ in various countries. In India, SCY loss in Bt cotton hybrids during 2008-09 to 2010-11 ranged from 7.2 to $80.1 \%$ based on disease severity grades one to four and PDI ranged from $0.08-59.5 \%$ (Monga et al., 2011). In Punjab, this disease reduced cotton production by almost $70 \%$ in 1998 (Mann, 2011). Similarly, in Punjab and Haryana, during 2009-12 and 2012-14 the reduction of SCY ranged between $25.2-46.6 \%$ and $15.7 \%$ to $56.7 \%$, respectively (Monga et al., 2012; Monga, 2014). CLCuD caused reduction in plant height $(40.5 \%)$, boll weight $(42.5 \%)$, number of bolls per plant $(86 \%)$ ginning outturn $\%(18.2 \%)$, staple length (7.1\%), fibre fitness $(23.8 \%)$ and SCY $(87.3 \%)$ in susceptible cotton cultivars in Pakistan (Ahmed et al., 2002). Singh et al. (2013) have reported $52.7 \%$ and $46.1 \%$ reduction in the number of bolls, $54.2 \%$ and $43.4 \%$ in boll weight in $\mathrm{RCH}-134$ and MRC-6304 hybrids, respectively. However, the past studies have not compared the disease-resistant and susceptible cultivars (BG II) and reduction of SCY corresponding time of incidence of CLCuD. Thus, this study provides new findings on reduction of SCY corresponding to disease incidence at different days after sowing in highly resistant, moderately resistant, and susceptible cotton bollgourd II hybrids.

The observations on fiber quality data revealed reduction in $2.5 \%$ span length, uniformity ratio and fiber strength in general in case of CLCuD compared to healthy control. There was not much change in micronaire values when data of CLCuD affected plants was compared with healthy control. The fiber length at 50 DAS ranged from 23.9-28.1 $\mathrm{mm}$ with an average of $25.9 \mathrm{~mm}$ as compared to $26.2-29.2 \mathrm{~mm}$ with an average of $27.6 \mathrm{~mm}$ in control. The uniformity ratio ranged from $62.5-82 \%$ with average at $68.2 \% 50$ DAS compared to $64.5-83.0 \%$ with an average of $72.9 \%$ in control. The fiber strength ranged from 21.4-28.6 with an average at 24.4, 50 DAS compared to 23.0-30.1 with an average of 25.9 in control. The effect of CLCuD progress on seven $\mathrm{Bt}$ cultivars having different resistance level on fibre quality showed the reduction of $2.5 \%$ span length, fibre uniformity as well as fibre strength and increase up to little extent $(1.1 \%)$ in micronnaire indicating reduction in fineness when CLCuD incidence took place at a very early state (50 DAS) (Fig.3). 
Similar to this study, the reduced fibre length $(2.6$ to $14.4 \%)$, fibre strength $(1.0-6.1)$ and uniformity $(1.6-2.2 \%)$ were reported due to CLCuD by Ahmad et al. (2002) and Singh (2006). Singh et al. (2013) also reported reduced fibre length from 29.1 to $26.2 \mathrm{~mm}(9.9 \%)$; fibre uniformity from 68.9 to 68.1 $\%$ (1.1\%); fibre strength from 29.1 to $26.9 \mathrm{~g}$ per texture $(7.5 \%)$ and miconaire value from 5.2 to $5.0 \mathrm{~g} \mathrm{inch}^{1}(3.8 \%)$. The earlier studies were conducted with respect to disease rating scale and fibre quality, however, our study correlates the stage of incidence and its effect on fibre quality parameter. The trend polynominal line for the effect of CLCuD on $2.5 \%$ span length, fibre uniformity and fibre strength also showed a reducing trend up to 125 days and thereafter it increased slightly (Fig. 3). However, the trend polynominal line for the effect of CLCuD on micronaire value was increased up to 110 days and thereafter it showed a decreasing trend. The reduced micronaire value (4.1$6.3 \%$ ) in CLCuD infected plants was however recorded by Singh (2006), Singh et al. (2013) but Ahmad et al. (2002) found increased micronaire value up to $13.9 \%$. Association of increase or decrease in micronaire value with CLCUD incidence could not be established, hence, it remains unclear and requires further investigations based on physiological studies. The previous studies conducted by Ahmad et al. (2002), Singh (2006), Singh et al. (2013) could not clarify the effect of incidence of CLCUD at various crop growth stages on yield and its quality components of cotton cultivars having varied resistance level.

The results of the present study indicated that the CLCuD has significant effect on SCY and its quality parameters and early incidence will result in more loss of yield and quality, but the response is varied with the CLCuD incidence as well as the level of resistance of Bt cultivars. The reduction in yield and its quality parameters does not necessarily be the same in all the Bt cotton cultivars. Hence, we hypothesize that all the hybrids have different genetic yield potential as well as their susceptibility to CLCuD. Yield reduction though dependent on the time of incidence and severity of CLCuD yet, the extent of yield reduction within their respective category is also dependent on the yield potential of a particular cultivar.

The yield and CLCuD tolerance are governed by two different genetic backgrounds. However, the disease tolerance coupled with higher genetic yield potential can be considered for selecting high yielding cotton hybrids and one must consider both the criteria to have higher SCY in the presence of CLCuD. The study is a first-of-its-kind which shows the effect of time of CLCuD incidence on SCY and other quality parameters of BGII hybrids with different levels of resistance and would be useful for future cotton breeding improvement programmes throughout the Indian subcontinent where CLCuD is a major constraint in cotton productivity enhancement.

\section{Acknowledgments}

The authors are thankful to the Indian Council for Agricultural Research-Central Institute for Cotton Research,
Regional Station, Sirsa for providing necessary laboratory and field facilities, and funding during the course of the investigation.

\section{Add-on Information}

Authors' contribution: D. Monga: Conceived, designed and performed field experiments, edited MS; S. K. Sain: performed experiment, contributed data analysis, writing and editing the MS.

Research content: The research contents is original and has notbeen published elsewhere

Ethical approval: NotApplicable.

Conflict of interest: The author declares that there is no conflict of interest.

\section{Data from other sources: NotApplicable}

Consent to publish: All authors agree to publish the paper in Journal of Environmental Biology.

\section{References}

Ahmad, G., S.A. Malik, Z. Mamood, M.Z. Iqbal and S. Ahmad: Effect of cotton leaf curl virus disease on morphology, yield and fibre characteristics of susceptible lines/cultivars of cotton (Gossypium hirsutum L.). Asian J. PI. Sci., 1, 705-707 (2002).

Ali, M.A., N.N. Nawab, A. Abbas, M. Zulkiffal and M. Sajjad. Evaluation of selection criteria in Cicer arietinum L. using correlation coefficients and path analysis. Aust. J. Crop Sci., 3, 65-70 (2009).

Briddon, R.W. and J. Stanley: Subviral agents associated with plant single-stranded DNA viruses. Virology, 344, 198-210 (2006)

Briddon, R.W. and P.G. Markham: Cotton leaf curl virus disease. Virus Res., 71, 151-159 (2001).

Brown, J., F.M. Zerbini, J. Navas-Castillo, E. Moriones, R. Ramos-Sobrinho and J.F. Silva: Revision of Begomovirus taxonomy based on pairwise sequence comparisons. Arch. Virol., 160, 1593-1619(2015).

Datta, S., R. Budhauliya, B. Das, R. Gopalakrishnan, S. Sharma, S. Chatterjee, P.R.V. Srinivas and V. Veer: Rebound of Cotton leaf curl Multan virus and its exclusive detection in cotton leaf curl disease outbreak, Punjab (India), 2015. Scientific Reports, 7, 17361 (2017).

Farooq, A., J. Farooq, A. Mahmood, A. Batool, A. Rehman and A. Shakeel: An overview of cotton leaf curl virus disease (CLCuD) a serious threat to cotton productivity. Aust. J. Crop Sci., 5, 1823-1831 (2011).

Farooq, J., M. Anwar, M. Riaz, A. Mahmood, A. Farooq, M.S. Iqbal and M.S. Iqbal: Association and path analysis of earliness, yield and fiber related traits under cotton leaf curl virus (CLCuV) intensive conditions in G. hirsutum L. PI. Knowledge J., 2, 43-50 (2013)

Farooq, J., A. Farooq, M. Rizwan, V.I. Petrescu-Mag, M.A. Ali, K. Mahmood and A. Batool: Cotton fibers: Attributes of specialized cells and factors affecting them. Adv. Environ. Sci. Int. J. Bioflux Soci., 7, 369-382 (2015).

Hussain, S., T. Mahmood, M. Tahir, H.T. Mahmood and M.N. Afzal: Differential effect of planting time on cotton leaf curl disease (CLCuD) and yield of cotton variety Cim-598 (Gossypium Hirsutum L.). Int. J. Novel Res. Life Sci., 2, 1-7 (2015).

Javed, M., S.B. Hussain and M. Baber: Assessment of genetic diversity 
of cotton genotypes for various economic traits against cotton leaf curl disease (CLCuD). Genet. Mol. Res., 16, 1 (2016).

Mahmood, T., M. Arshad, M.L. Gill, H.T. Mahmood, M. Tahir and S. Hussain: Burewala strain of cotton leaf curl virus: A threat to CLCuV cotton resistant varieties. Asian J. PI. Sci., 2, 968-970 (2003).

Mann, R.: Bemisia tabaci interaction with cotton leaf curl virus. In: The Whitefly, Bemisia tabaci (Homoptera: Aleyrodidae) interaction with Geminivirus-Infected host plants (Ed.: W.M.O Thompson). Springer Netherlands, pp. 69-88 (2011).

Monga, D., P.K. Chakrabarty and K.R. Kranthi: Cotton leaf curl disease in India-recent status and management strategies. Doi:http:// staging.icac. org/tis/regional_networks/asian_network/meeting_ 5/documents/papers/PapMongaD.pdf(2011).

Monga, D., A.M. Narula and S. Raj: Management of cotton leaf curl virusA dreaded disease in North India. National Seminar on Sustainable Cotton Production to Meet the Future Requirement of Industry. Kapas Vikas Nideshalya, Directorate of cotton development, Government of India, pp.112-115 (2001).

Monga, D., P.S. Sekhon, J. Beniwal, D. Singh, P.V. Patil, P.K. Dhoke, O.V. Ingole, R.R. Perane, S.N. Chattannavar, B. Sree Lakshmi and M.L.S. Rao: Avoidable losses due to cotton diseases in India. In: Global Cotton Production Technologies vis-a-vis Climate Change (Eds.: S.S. Siwach, R.S. Sangwan, M.S. Chauhan and O. Sangwan). Cotton Research and Development Association, pp. 62-67 (2012)

Monga, D.: Cotton Leaf Curl Virus diseases. CICR Technical Bulletin, p.34 (2014).

Monga, D.: Cotton leaf curl virus diseases: An overview. Agric. Res. J., 53, 466-474 (2016).

Naveen, N.C., R. Chaubey, D. Kumar, K.B. Rebijith, R. Rajagopal, B. Subrahmanyam and $S$. Subramanian: Insecticide resistance status in the whitefly, Bemisia tabaci genetic groups Asia-I, Asia-II1 and Asia-II-7 on the Indian subcontinent. Scientific Reports, 7 , 40634 (2017).
Rahman, M. and Y. Zafar: Registration of NIBGE-115 cotton. J. Plant Regist., 1, 51-52 (2007).

Saeed, F., J. Farooq, A. Mahmood, T. Hussain, M. Riaz and S. Ahmad: Genetic diversity in upland cotton for cotton leaf curl virus disease, earliness and fiber quality. Pakistan J. Agric. Res., 27, 3, 226-236 (2014a).

Saeed, F., J. Farooq, A. Mahmood, M. Riaz, T. Hussain and A. Majeed: Assessment of genetic diversity for Cotton leaf curl virus (CLCuD), fiber quality and some morphological traits using different statistical procedures in Gossypium hirsutum L. Australian J. Crop Sci., 8, 442-447 (2014b).

Sattar, M.N., Z. Iqbal, M.N. Tahir and S. Ullah: The prediction of a new CLCuD epidemic in the old world. Front. Microbiol., 8, 631 (2017).

Sheoran, O.P., D.S. Tonk, L.S. Kaushik, R.C. Hasija and R.S. Pannu: Statistical Software Package for Agricultural Research Workers, In: Recent Advances in information theory, Statistics and Computer Applications (Eds.: D.S. Hooda and R.C. Hasija). Department of Mathematical Statistics, CCS HAU, Hisar, India, pp.139-143 (1998).

Singh, D., J.S. Gill, R.K. Gumber, R. Singh and S. Singh: Yield and fibre quality associated with cotton leaf curl disease of Bt cotton in Punjab. J. Environ. Biol., 34, 113-116 (2013).

Singh, D.: Effect of symptom grades of cotton leaf curl disease on the yield and quality of fibre of upland cotton in Punjab. Indian Phytopath., 59, 148-153 (2006).

Wilcoxson, R.D., B. Skovmand and A.A. Atif: Evaluation of wheat cultivars for the ability to retard development of stem rust. Ann. Appl. Biol., 80, 275-287(1975).

Zerbini, F.M., R.W. Briddon, A. Idris, D.P. Martin, E. Moriones, J. NavasCastillo, R. Rivera-Bustamante, P. Roumagnac and A. Varsani: ICTV virus taxonomy profile: Geminiviridae. J. Gen. Virol., 98, 131-133 (2017). 